DOI https://doi.org/10.36059/978-966-397-207-7/57-75

\title{
DRUG CRIME REDUCTIOM FROM THE VICTIM POSITION
}

\section{Klymiuk I. N.}

\section{INTRODUCTION}

In the system of measures to ensure the criminological safety of society, the fight against crime in the sphere of illicit trafficking in narcotic drugs, psychotropic substances, their analogues and precursors occupies an important place. The issue under investigation has been a problem for many centuries and has become increasingly relevant lately. The paper proposes an approach to reducing the level of narcotic crime from the point of view of victimology.

Narcotic victimization is a person's inclination, under favorable circumstances, to become a victim of a crime, including the sale or use of drugs. Given that victimization is a process of transforming potential victims into victims of crime, individuals are subconsciously endowed with internal victimization.

Schematically, victimization can be divided into several steps:

1. Occurrence of victimization;

2. Creation of a criminal situation;

3. Realization of victimization by criminal assault;

4. Post-criminal behavior of victims of crime.

\section{Mechanism of criminal behavior of the addict}

The crime is committed as a result of certain patterns. They are quite different for each crime, so it is necessary to take into account the circumstances that led to his commission, the criminal's external environment, his personal qualities and beliefs, education, education and even religion. Recognizing the influence of individual factors of the social environment, psychological substructures of the individual, his motivational sphere, they are dynamically transformed and affect other elements of the mechanism of individual criminal behavior.

Since crime as a result is a form of interaction between the individual and the environment, the stages that serve to shape 
criminal behavior must be considered against the background of social reality.

The mechanism of criminal behavior is as follows:

1) formation of personality with antisocial orientation;

2) motivation for antisocial behavior (motivational stage);

3) making a specific decision on its implementation (the stage of design);

4) implementation of the decision;

5) post-criminal behavior ${ }^{1}$.

The appropriate behavior of a person at each stage is the result of the interaction of the environment and the person committing the crime.

At each of the stages of interaction of the person with the environment is different, the subject may be more or less active, and at the last stage he becomes the most active: it can affect social reality in a negative direction, which as a consequence causes appropriate sanctions from the party society (deprivation of liberty or other punishment). There are also different timelines for the stages of criminal behavior: antisocial orientation can take a long time, while motivation and decision-making may take days or hours, and implementation may take several minutes.

The above scheme is rather conditional because, for example, the decision-making stage may be completely absent (negligent crime) or last for years or within seconds (a crime of physiological affect).

From a psychological point of view, a person actively acts only on what is of value to him. But the values of the offender are individual, they do not coincide with the conventional and have not a positive but a socially negative orientation. Thus, the social danger of the offender is determined not by some of his special needs and values, but by his rejection of the system of already existing social values.

Motivation to commit a crime is an internal motivation, the driving force behind the commission of a criminal act.

The motives can be quite different: low (for example, self-interest, revenge, hooliganism); those that are not of a low nature (for

${ }^{l}$ Бажанов М.I., Баулін Ю.В., Борисов В.І. Кримінальне право України: Загальна частина: Підручник / За ред. проф. М.І. Бажанова, В.В. Сташиса, В.Я. Тація. -2-е вид., перероб. і допов. - Київ : Юрінком Інтер, 2005. - С. 162. 
example, pity, sympathy, the desire to help another person $)^{2}$. Motives can also be attributed to a person's conscious needs (food, clothing, shelter, communication, acquaintance, leisure), both real and imagined, that drive her to act. Behavior motives are determined by feelings, needs, interests that arose and sharpened under the influence of the environment and in a particular situation.

Analyzing the aforesaid it is possible to identify the following motives for crimes in the field of drug trafficking in psychotropic substances:

1. Organic motive - the thirst for the body to take a drug (addiction);

2. Self-interest - lack of funds, confidence in the need to improve living standards.

When deciding to commit a crime, the occurrence of possible consequences is forecasted, taking into account the real situation, own capabilities and other circumstances. After the person under the influence of the situation and the existing needs, interests, feelings, there is a setup for certain behavior, there is some delay. As a rule, a person does not act immediately in accordance with this setting, but relates it to existing in the society of moral, legal and other norms, with public and group opinion, with the opinion of relatives. Objective factors, such as the state of external social control, are taken into account. It also takes into account the practice of detecting, ending a crime, punishing perpetrators. In doing so, the possible benefits and losses are weighed. At this stage, the characteristics of the consciousness of the individual, as well as of the persons and groups in contact with whom the person is or is oriented, become essential. If the decision is delayed, there may be a refusal to commit a crime, for example as a result of the awareness that such crimes are usually disclosed and the perpetrators are held to strict liability. If a person does not refuse the decision to break the law, he chooses the means of achievement of the goal, which seem to him in the appropriate situation most appropriate, taking into account his own capabilities and the capabilities of accomplices.

2 Бажанов М.І., Баулін Ю.В., Борисов В.І. Кримінальне право України: Загальна частина: Підручник / За ред. проф. М.І. Бажанова, В.В. Сташиса, В.Я. Тація. - 2-е вид., перероб. і допов. - Київ : Юрінком Інтер, 2005. - С. 167. 
Based on the nature of the «narcotic» crimes, the decision-making stage is quite important. As an example, consider Article 305 of the Criminal Code of Ukraine - smuggling of narcotic drugs, psychotropic substances, their analogs or precursors or counterfeit medicines. While moving illicit substances across the customs border of Ukraine, a person may be guided by his or her own beliefs, for example, when transporting the drugs he / she uses; or have incited him to do so, and he is acting as the executor, although in reality he can only be an accomplice, assisting in the commission of a crime by carriage; or he may not be aware of the contents of the luggage he is carrying. When deciding on drug smuggling at the suggestion of the customer, the person must know what is being transported, then he or she will be able to weigh all the advantages and disadvantages of the act and agree, or refuse, but the responsibility for committing the crime comes regardless of the carrier's awareness of the baggage content.

At the stage of realization of the intent is the execution of the planned crime. The peculiarity of the execution is the interaction of accomplices among themselves, between the offender and his victim, between the offender and third parties (witnesses and eyewitnesses). The actual implementation of the solution may differ from the one planned, for example, when the external situation changes. It is important to find out why the decision was made to choose the most criminal behavior. After all, motive and purpose in themselves may not be anti-social in nature, but criminal behavior can make the chosen means of achieving the goal.

That is, at this stage, the most important thing is the commission of a direct crime. Understanding the mechanism of crime is an important element in preventing criminal acts, since knowing the problem from the inside is easier to solve. It is possible to distinguish the following causal links (stages of commission) of crimes of this subgroup: preparation; implementation; concealment.

A clearly depicted model of the crime practically coincides with the mechanism of criminal behavior of the person, but is more narrowed. Based on the situation, it is logical to design and model of search for drugs, psychotropic substances, their analogues and precursors. On the objective side, in order to find «narcotic 
substances» you need to know them: storage method; method of sale; way of hiding.

At the stage of post-criminal behavior, the perpetrator analyzes what has happened, the consequences that have occurred, hides the traces of the crime, disposes of the acquired property, takes measures to legalize (launder) the property, as well as to avoid criminal liability and punishment (threats, elimination bribery of law enforcement or control officers).

All this corresponds to the norms of morality, law, public opinion, group assessments. The person can either repent of the committed or develop a system of protection against exposure. For example, she may claim that the drugs were tossed, that they were not him (or her), or had just been found by a person on the road, and were immediately seized by law enforcement officers.

Thus, the mechanism of criminal behavior is the process of interaction between the individual and the environment during which intent is created, planned and committed. The mechanism of criminal behavior reveals its structural elements and their interaction in dynamics. It can help to consider the chain of development of criminal behavior: the interaction of causes and conditions that give rise to the motive and intent to commit the crime, deciding and planning the assault, the specific life situation and behavior of the victim, the execution of the planned crime and its consequences.

In order to combat drug crime, it is advisable to carry out victimmodeling using existing criminal cases as a model, based on the information recorded in the register of judicial decisions of Ukraine. According to which, «person 1» came from Izmail to Odessa and in the morning purchased a large batch of cannabis at the train station, after which he was detained by law enforcement. On interrogation, "person 1" confessed to the crime, claiming that he had purchased the drug solely for his own use and in small quantities ${ }^{3}$.

In order to determine what liability to apply to a particular case (administrative or criminal liability), it is necessary to establish the amount of drugs and psychotropic substances. This can be done by

3 Офіційний сайт Реєстр судових рішень. Справа № 500/4294/14-к. [Електронний ресурс]: Режим доступу: http://www.reyestr.court.gov.ua/ Review/42858627. 
examining tables of small, large and particularly large quantities of narcotic drugs, psychotropic substances and precursors that are in illicit use ${ }^{4}$.

The law provides for administrative liability for a given subset of crimes, namely, for the illicit manufacture, purchase, storage, transportation, transfer of narcotic drugs or psychotropic substances without the purpose of small-scale sales ${ }^{5}$. For example, according to the table, small size is considered: up to $5.0 \mathrm{~g}$ of cannabis, cannabis resin; up to $0.3 \mathrm{~g}$ of cannabis extract (tincture) - a remedy obtained from any kind and variety of cannabis or cannabis by extraction in various ways and containing tetrahydrocannabinol; up to $0.005 \mathrm{~g}$ of heroin; up to $0.005 \mathrm{~g}$ acetylated opium - a means containing; acetylated derivatives of opium alkaloids (including other substances); up to $0.2 \mathrm{~g}$ of codeine; up to $0.02 \mathrm{~g}$ of cocaine; to $0.03 \mathrm{~g}$ of morphine; up to $0.1 \mathrm{~g}$ of opium 6 .

That is, if these or similar narcotic substances are discovered, their illicit manufacture, purchase, storage, transportation, shipment without the purpose of sale - entail a fine of twenty-five to fifty taxfree minimum incomes or community service for a term from twenty to sixty hours, or administrative arrest for up to fifteen days. In addition, a person who voluntarily surrendered narcotic drugs or psychotropic substances that were small in size and manufactured, manufactured, purchased, stored, transported, forwarded without the

4 Невеликі, великі та особливо великі розміри наркотичних засобів, що знаходяться у незаконному обігу/Таблиця 1/ Затверджена наказом Міністерства охорони здоров'я України $01.08 .2000 \mathrm{~N} 188$ (у редакції 19.06.2015): [Електронний ресурс]. - Режим доступу: http://zakon2.rada.gov.ua /laws/show/z0512-00.

${ }^{5}$ Кодекс України про адміністративні правопорушення (статті 1 - 212-21) від 07.12.1984 № 8073-Х (у редакції 16.04.2017): [Електронний ресурс]. Режим доступу: http://zakon2.rada.gov.ua/laws/show/80731-10.

${ }^{6}$ Невеликі, великі та особливо великі розміри наркотичних засобів, що знаходяться у незаконному обігу/Таблиця 1/ Затверджена наказом Міністерства охорони здоров'я України 01.08.2000 N 188 (у редакції 19.06.2015): [Електронний ресурс]. - Режим доступу: http://zakon2.rada.gov.ua/laws/show/ z0512-00. 
purpose of sale, shall be exempt from administrative responsibility for actions ${ }^{7}$.

However, if the same narcotics are larger, then criminal liability under the Criminal Code of Ukraine (Section XIII) applies. An examination of narcotic drugs or psychotropic substances should be conducted to provide accurate information on the size of the materials being tested. If the size of the cannabis is small, such as $3 \mathrm{~g}$, then administrative liability is applicable. If $5 \mathrm{~g}$ or more - criminal.

In this case, the preparation for committing a crime (moving to another city) for the purchase of drugs is clearly traced; it is a completed crime because the drug is purchased. The purpose - to get pleasure from drug intoxication, direct intent. Actions of «person 1» can be qualified under part 1 of Article 309 of the Criminal Code of Ukraine - illegal production, manufacture, purchase, storage, transportation or transfer of narcotic drugs, psychotropic substances or their analogues without the purpose of sale. Liability for which is a fine of fifty to one hundred tax-free minimum incomes, or correctional labor for a term up to two years, or arrest for up to six months, imprisonment for a term up to three years, or imprisonment for the same term ${ }^{8}$.

However, when determining a sentence, the court also takes into account factors that may contribute to the aggravation or mitigation of the sentence. One of the mitigating circumstances explicitly stated in part 4 of Article 309 of the Criminal Code of Ukraine - voluntary referral to a medical institution and the commencement of treatment for drug addiction, releases from criminal liability. Also mitigating circumstances include: committing a crime to a minor, committing it for the first time, taking into account the scale of the acts committed, the consequences they led to and the size of the drugs; committing a crime as a result of grave personal family circumstances, committing under the influence of coercion, threats, or through material or

${ }^{7}$ Кодекс України про адміністративні правопорушення (статті 1 - 212-21) від 07.12.1984 № 8073-Х (у редакції 16.04.2017): [Електронний ресурс]. Режим доступу: http://zakon2.rada.gov.ua/laws/show/80731-10. - Ст. 44.

8 Кримінальний кодекс України від 05.04.2001 № 2341-III (у редакції 16.04.2017): [Електронний ресурс]. - Режим доступу: http://zakon3.rada.gov.ua/ laws/show/2341-14. - Ст. 309. 
official dependence, etc. The aggravating circumstances are referred to in paragraph 2 of Article 309 of the Criminal Code of Ukraine the commission of a crime again or by prior conspiracy by a group of persons or a person who has previously committed one of the crimes provided for by Articles 307, 308, 310, 317 of the Criminal Code of Ukraine $^{9}$, or if the subject matter such actions were narcotics, psychotropic substances or their analogues in large sizes; and in accordance with Article 309 (3) of the Criminal Code of Ukraine committing with the involvement of a minor, as well as if the object of such acts were narcotic drugs, psychotropic substances or their analogues of particularly large size.

In addition, to determine the true intent of the suspect, it is necessary to conduct interrogation of persons from his immediate environment. They can provide important information for a quality case study and, as a consequence, for a speedy solution. It may be possible to obtain information about the purchase of drugs by a person in the past or their distribution to a suspect; schemes for obtaining and selling drugs; persons involved in committing the crime (organizer, executor, guide, instigator), etc.

All these circumstances will enable the investigator to investigate the crime in a quality manner and to establish justice. Scientists, on the basis of the investigated aspects, - to develop a homogeneous model of behavior of criminals in the sphere of drug business development and to develop effective methods for reducing the criminogenic situation in Ukraine. Provide assistance to drug addicts; to overcome organized crime in the sphere of drug and psychotropic substances, their analogues and precursors. To find effective methods to prevent potential victims from falling into such situations and, in view of the particular nature of the crime, not to become criminals.

In the present case, Person 1 is both a thief and a victim of drugs. In addition, other criminals are appearing - persons who have sold him drugs whose actions can be qualified under Article 306 of the Criminal Code of Ukraine, 307, 311, etc., of course, proving their guilt.

9 Кримінальний кодекс України від 05.04.2001 № 2341-III (у редакції 16.04.2017): [Електронний ресурс]. - Режим доступу: http://zakon3.rada.gov.ua/ laws/show/2341-14. - Ст. 309. 
In addition, one should not forget about patrolmen, how they "could" throw narcotic substances to "person 1"; about rail security that could know about business on the railroad and above standing. The profits from the drug business are enormous! Some criminal groups can be headed even by board members, not to mention medical personnel, the military, which is now particularly prevalent.

Knowing the existence of "points" of sale of drugs, it is necessary to report it to law enforcement agencies. try not to fall within the scope of their activities. There is a need to increase control over the stations: road, rail, river and seaports. Conduct patrols with specially trained dogs and involve the latest developments in science and technology. Because if the drug dealer was detained by the police before he sold them, then the person who bought them would not be able to buy the cannabis, that is, the crime could not have happened.

Under the circumstances of the second case, "Person 2" purchased amphetamine and successfully sold it at a school site (two cases are known), after which he was detained by police. Person 2 is a drug addict and has chronic hepatitis and HIV infection ${ }^{10}$.

In this case, several persons are victims at the same time: "Person 2" - a drug addict who bought and started selling drugs, two people to whom he sold them, and students attending the school. Probably «itself 2 » was engaged in similar "sales" not the first time, and, most likely, has more than one «point of sale». Due to the fact that he himself is ill with drug addiction, so he uses drugs, he can be traced to a larger thief. "Person 2" needs to help reduce the suffering of drug addiction, "cover up" his business, having previously learned about customers. Criminal offenses are more socially dangerous when it comes to the distribution of narcotic and psychotropic substances in public places. Especially in the school district, where many kids, young people who are interested in everything around, try to seem "cooler" from each other, especially during adolescence.

We model the situation. "Person 2" approached "Person 3" (Grade 10 student) and purchased amphetamine, after which "Person 3" treated his friend "Person 4" and they later began to buy

10 Офіційний сайт Реєстр судових рішень. Справа № 486/1038/15-к. [Електронний ресурс]: Режим доступу: http://reyestr.court.gov.ua/Review/ 54746382. 
"Person 2" drugs to order. Due to the fact that "person 3" and "person 4" are students, and they do not have much money, they start selling drugs at a higher price themselves. In cases where they are not bought, they demand money from smaller, weaker students or steal from their parents and neighbors.

In order to prevent the development of this situation, it is necessary to strengthen the control over the school districts, since the responsibility for the children lies with the teachers. If the school district is fenced off and a guard is put in place, the "person 2" distributor will not be able to penetrate the school grounds, so the students will have less chance of access to drugs, therefore the drugs will cease to be distributed.

\section{Elements of crime in the sphere of drug and psychotropic substances circulation, their analogues and precursors through the prism of victimization}

The object of victimization is the public relations of which persons, goods, rights, interests and interests of which are threatened by criminal acts, are involved. These are the so-called potential victims, whose scope is defined by the sphere of criminal protection $^{11}$. The object of crimes in the sphere of trafficking in narcotic drugs and psychotropic substances, their analogues and precursors is the legal regime for the circulation of narcotic drugs, psychotropic substances and precursors ${ }^{12}$. A specific crime group is characterized by an additional object. Thus, theft of narcotics or psychotropic substances $^{13}$ (Article 308 of the Criminal Code), along with health, damage to property relations, and in the case of unlawful issuance of a prescription for the right to purchase drugs or

11 Сайт Укрінформ. [Електронний ресурс]: Режим доступу: http://www.ukrinform.ua/ukr/news/urugvay_legalizuvav_marihuanu_1895217.

12 Науково-практичний коментар до Кримінального Кодексу України [Електронний ресурс]. - Режим доступу: http://pravoznavec.com.ua /books/162/28\#chlist

13 Кримінальний кодекс України від 05.04.2001 № 2341-III (у редакції 16.04.2017): [Електронний ресурс]. - Режим доступу: http://zakon3.rada.gov.ua/ laws/show/2341-14. - Ст. 308. 
psychotropic substances $^{14}$ (Article 319 of the Criminal Code), the normal activity of the respective institutions. Property relations and the normal activities of businesses and institutions in such cases act as additional objects of encroachment.

The vast majority of crimes in this category require the identification of the subject of the attack. Most items related to illicit trafficking in narcotic drugs, psychotropic substances, their analogues and precursors are listed in Tables I-IV ${ }^{15}$. The subject of this type of crime are drugs, psychotropic substances and their analogues. The rules of Art. 1 of the Law of Ukraine "On Narcotic Drugs, Psychotropic Substances and Precursors ${ }^{16 "}$ provides definitions of these concepts.

The objective side of victimization includes the situation in which the attack occurred (location, time, method of harm), as well as the victim's behavior ${ }^{17}$.

The objective side is characterized by acts in the form of active actions: abduction, misappropriation, extortion of narcotic drugs, psychotropic substances or their analogues or seizure of them by fraud or abuse of office (Article 308 of the Criminal Code); illegal production, manufacture, purchase, storage, transportation, transfer (Article 309 of the Criminal Code), inclination to use drugs, psychotropic substances or their analogues (Article $315 \mathrm{KK}$ ); encouragement of minors to use doping (Article 323 of the Criminal Code). Such crimes as violations of the established rules of circulation of narcotic drugs, psychotropic substances, their analogs or precursors (Article 320 of the Criminal Code), violations of

14 Кримінальний кодекс України від 05.04.2001 № 2341-III (у редакції 16.04.2017): [Електронний ресурс]. - Режим доступу: http://zakon3.rada.gov.ua/ laws/show/2341-14. - Ст. 319.

15 Невеликі, великі та особливо великі розміри наркотичних засобів, що знаходяться у незаконному обігу/Таблиця 1/ Затверджена наказом Міністерства охорони здоров'я України $01.08 .2000 \mathrm{~N} 188$ (у редакції 19.06.2015): [Електронний ресурс]. - Режим доступу: http://zakon2.rada.gov.ua /laws/show/z0512-00.

16 Закон України « Про наркотичні засоби, психотропні речовини $\mathrm{i}$ прекурсори» від 15.02.1995 № 60/95-ВР (у редакції 28.12.2015): [Електронний pecypc]. - Режим доступу: http://zakon2.rada.gov.ua/laws/show/60/95-вр. - Ст. 1.

${ }_{17}$ Ривман Д.В. Криминальная віктимологія : учеб. / Д. В. Ривман. - СПб. : Питер, 2002. - С. 82. 
sanitary rules and norms for the prevention of infectious diseases and mass poisoning (Article 325 of the Criminal Code), as well as violations of the rules of treatment of microbiologists other biological agents or toxins (Art. 326 of the Criminal Code) may be committed both through action and inaction ${ }^{18,19}$.

Pursuant to paragraph 3 of the Resolution of the Plenum of the Supreme Court of Ukraine "On case-law on drug offenses, psychotropic substances, their analogues or precursors" ${ }^{20}$ under the illicit manufacture of narcotic drugs and (or) psychotropic substances all actions related to with the serial production of narcotic drugs, psychotropic substances from chemicals and (or) plants, including the separation of parts of plants or narcotic drugs, psychotropic substances from the plants from which they are obtained, carried out against the mouth new law. The serial production of narcotic drugs, psychotropic substances from chemicals and (or) plants should be understood as a production process aimed at obtaining batches of narcotic drugs, psychotropic substances according to the relevant technology, standard, model.

Illegal production of narcotic drugs, psychotropic substances are all actions taken contrary to the procedure established by law, which result in the preparation and use of a form of narcotic drugs, psychotropic substances on the basis of narcotic drugs, psychotropic substances, drug precursors and psychotropic substances. or medicines containing them, or other narcotic drugs, psychotropic substances.

The illicit manufacture of precursors should be understood as the process of obtaining them from the appropriate raw material by any

18 Кримінальний кодекс України від 05.04.2001 № 2341-III (у редакції 16.04.2017): [Електронний ресурс]. - Режим доступу: http://zakon3.rada.gov.ua/ laws/show/2341-14. - Ст. 308, 309, 315, 323, 320, 325, 326.

19 Науково-практичний коментар до Кримінального Кодексу України [Електронний ресурс]. - Режим доступу: http://pravoznavec.com.ua /books/162/28\#chlist.

20 Постанова пленуму Верховного суду України « Про судову практику в справах про злочини у сфері обігу наркотичних засобів, психотропних речовин, їх аналогів або прекурсорів» від 26.04.2002 № 4 (у редакції 18.12.2009): [Електронний ресурс]. - Режим доступу: http://zakon2.rada.gov.ua/laws/ show/v0004700-02. 
means, in any form (powder, liquid, mixture, etc.), preparation by mixing different chemicals or chemical synthesis (reaction). The illicit manufacture of narcotic drugs, psychotropic substances forms the finished composition of the crime from the moment when the actions aimed at obtaining such drugs or substances ready for use, or to refining or increasing in their concentration of drugs, began to take place.

The purchase of drugs, psychotropic substances, their analogues or precursors should be considered as illegal purchase, exchange for other goods or things, acceptance as payment for work performed or services rendered, loans, gifts or debt payments, appropriation of the found. Illegal acquisition also refers to the collection of remnants of drug-containing plants in the harvested land after removal of the protection, on the land plots of citizens, as well as the collection of such wild plants or parts of them on vacant lots.

Unlawful storage means any deliberate action related to the actual unlawful possession of narcotic drugs, psychotropic substances or their precursors in the possession of the perpetrator (he may keep them with him, in any premises, storage or other place). In addition, the responsibility for illegal storage arises regardless of its duration.

Illegal carriage of narcotic drugs, psychotropic substances, their analogues or precursors is the deliberate movement of any kind of transport within the territory of Ukraine in violation of the procedure and rules established by the current legislation. The transportation of drugs, psychotropic substances, their analogues or precursors should be distinguished from their transportation from one place to another, during which the transport is not used. Such actions should be considered as storage of these agents and substances.

Illegal shipment of narcotic drugs, psychotropic substances, their analogues or precursors is the unlawful movement of drugs, whether by mail, baggage, mail order or otherwise, from one place to another within the territory of Ukraine. The crime is considered to be completed from the moment of registration and departure of the parcel, baggage, letter, parcel post with these means or substances, regardless of whether the addressee received them or not. If the crime has not been completed for reasons beyond the control of the perpetrator, the latter's action shall be qualified as an attempt to commit the crime. 
The offenses provided for in Articles 307, 309 or 311 of the Criminal $\operatorname{Code}^{21}$ are recognized as having been completed from the moment of committing one of the alternative actions mentioned in the dispositions of these articles. In cases where the perpetrator committed one or more of these actions, but did not manage to take another action from those covered by the intent, the act should be considered as a completed crime by the actions performed, and the incomplete action of a separate qualification as preparation for crime or as an attempt to no crime is needed.

Illegal sale of narcotic drugs, psychotropic substances or their analogues (Article 307 of the Criminal Code), as well as precursors (part 2 of Article 311 of the Criminal Code) are any paid or free forms of their realization (sale, gift, exchange, payment of debt, loan, introduction by the owner) these drugs or injectables to another person with their consent, etc.). Sales are not co-administered injections of narcotic drug, psychotropic substance or their analogue by persons who have purchased them for common funds ${ }^{22}$.

The subject of victimization according to Rivman DV is: "The persons whose rights or interests are actually harmed by the crime ${ }^{23}$. The subject of these crimes is a natural convicted person who has reached the age of 16 . The exception is the abduction, misappropriation, extortion of drugs, psychotropic substances or their analogues, or the seizure of them by fraud or abuse of office (Article 308 of the Criminal Code), which provide for criminal liability from the age of 14 . In the course of qualifying a series of actions, it requires the identification of characteristics that are specific to the specific crime subject. Such are the illegal issuance of a

21 Постанова пленуму Верховного суду України « Про судову практику в справах про злочини у сфері обігу наркотичних засобів, психотропних речовин, ïx аналогів або прекурсорів» від 26.04.2002 № 4 (у редакції 18.12.2009): [Електронний ресурс]. - Режим доступу: http://zakon2.rada.gov.ua/laws/show/ v0004700-02.

22 Постанова пленуму Верховного суду України « Про судову практику в справах про злочини у сфері обігу наркотичних засобів, психотропних речовин, їх аналогів або прекурсорів» від 26.04.2002 № 4 (у редакції 18.12.2009): [Електронний ресурс]. - Режим доступу: http://zakon2.rada.gov.ua/laws/show/ v0004700-02. - Ст. 4.

23 Ривман Д.В. Криминальная віктимологія : учеб. / Д. В. Ривман. - СПб. : Питер, 2002. - С. 82. 
prescription for the right to purchase narcotic drugs or psychotropic substances (Article 319 of the Criminal Code); encouragement of minors to use doping (Article 323 of the Criminal Code) and others. If the act was made by a person who does not possess the characteristics of a special subject, the qualification for these articles is excluded.

The subjective side is the victim's "guilt", the motives and goals of its victim behavior ${ }^{24}$. "On the subjective side, crimes against the health of the population can be committed intentionally (overwhelmingly) and negligently. Actions manifested in violation of certain rules (violation of the established rules of circulation of narcotic drugs, psychotropic substances, their analogs or precursors (Article 320 of the Criminal Code), violation of sanitary rules and norms for the prevention of infectious diseases and mass poisoning (Article 325 of the Criminal Code), inherent in both forms of wine. For the qualification of a number of crimes, it is necessary to establish a special purpose, which is included in the dispositions of the relevant norms as a mandatory feature. These include, in particular, the illicit manufacture, manufacture, purchase, storage, transportation, or shipment of precursors for the purpose of using them to manufacture or manufacture narcotic drugs or psychotropic substances (Article 311 of the Criminal Code). ${ }^{25}$

Also important is the fault of the person who committed the crime, which is divided into intent and negligence. In most cases, this category of crimes is committed intentionally. Pursuant to paragraph 4 of the Resolution of the Plenum of the Supreme Court of Ukraine "On case law on criminal offenses in the sphere of narcotic drugs, psychotropic substances, their analogs or precursors ${ }^{26,}$, the intent to sell drugs, psychotropic substances, their analogs or precursors may testify an agreement with the person who purchased

${ }^{24}$ Ривман Д.В. Криминальная віктимологія : учеб. / Д. В. Ривман. - СПб. : Питер, 2002. - С. 82.

25 Кримінальний кодекс України від 05.04.2001 № 2341-III (у редакції 16.04.2017): [Електронний ресурс]. - Режим доступу: http://zakon3.rada.gov.ua/ laws/show/2341-14.

${ }^{26}$ Постанова пленуму Верховного суду України « Про судову практику в справах про злочини у сфері обігу наркотичних засобів, психотропних речовин, їх аналогів або прекурсорів» від 26.04.2002 № 4 (у редакції 18.12.2009): [Електронний ресурс]. - Режим доступу: http://zakon2.rada.gov.ua/laws/show/ v0004700-02. - Ст. 4. 
the products or substances, as well as other circumstances, including: large or particularly large; method of packaging and packaging; behavior of the subject of crime; the fact that the person does not use narcotic drugs or psychotropic substances himself, but manufactures and stores them; etc. It should be borne in mind that the responsibility for the sale of such agents and substances comes regardless of their size.

The actions of a person who, under the guise of narcotics, psychotropic substances, their analogs or precursors, intentionally sells any other means or substances for the purpose of seizing money or property, should be qualified as fraud, and if there is reason to do so, as inciting to attempted unlawful purchase of narcotic drugs, psychotropic substances, their analogues or precursors, the actions of the buyer - as an attempt to commit the crimes provided for in Article 307 or Article 309, or Article 311 of the Criminal Code.

In cases where a narcotic drug, psychotropic substance or their analogues has been simultaneously manufactured for both personal use and marketing, the offense is qualified on the basis of the crimes provided for in Articles 307 and 309 of the Criminal Code. It should be borne in mind that under Article 309 of the Criminal Code, the actions of the perpetrator must be qualified only in the part of the production, manufacture and storage of these agents and substances to the extent that he consumed or planned to use them. Money or other things obtained by a person for the sale of narcotic drugs, psychotropic substances, their analogues or precursors, are transferred to the state revenue on the basis of article 81 , paragraph 1 , section 1 of the Criminal Procedure Code of Ukraine ${ }^{27}$, except for those received during the operational purchase, which are to be returned to the legal to the owner. Responsibility for the abduction, misappropriation, extortion of narcotic drugs, psychotropic substances, their analogues, equipment intended for the manufacture of these drugs, substances and their analogues, as well as precursors, for seizing them by fraud or abuse of office by their official

27 Кримінальний процесуальний кодекс України від 13.04.2012 № 4651-VI (у редакції 14.04.2017): [Електронний ресурс]. - Режим доступу: http://zakon2.rada.gov.ua/laws/show/4651-17. - Ст. 81. 
position 8, according to Article 308, 313, 312 of the Criminal Code ${ }^{28}$ in case of deliberate unlawful withdrawal by any of these methods from enterprises, institutions and organizations irrespective of the form of ownership or in individual citizens, including the seizure of drugs. existing plants or parts thereof from land or households before the end of the harvest. It does not matter whether the person lawfully or illegally possessed a narcotic drug, psychotropic substance, their analogue or precursor, or cultivated narcotic plants that became the subject of illegal seizure.

According to the contents of Articles 308, Sections 1 and 2, Article 313, Sections 1 and 2, Article $312^{29}$ of the Criminal Code, responsibility for the theft of narcotic drugs, psychotropic substances, their analogues, equipment intended for their manufacture, or precursors arises in cases of unlawful secret or open, including the use of non-life-threatening or health-threatening violence, or the threat of such violence (with the exception of theft of such equipment), their removal from legal or natural persons who possess them both lawfully and $\mathrm{N}$ illegally (theft, robbery) ${ }^{30}$.

\section{CONCLUSIONS}

The most frequently occurring cases were selected to familiarize themselves with the criminal situation in Ukraine in the field of narcotic business and conducted victim-modeling. Ways to avoid getting into such situations were suggested and actions were recommended to help prevent the development of drugs, psychotropic drugs, their analogues and precursors. Investigation of the elements of the crimes in the sphere of drug and psychotropic drug trafficking,

28 Кримінальний кодекс України від 05.04.2001 № 2341-III (у редакції 16.04.2017): [Елекронний ресурс]. - Режим доступу: http://zakon3.rada.gov.ua/ laws/show/2341-14.

29 Кримінальний кодекс України від 05.04.2001 № 2341-III (у редакції 16.04.2017): [Електронний ресурс]. - Режим доступу: http://zakon3.rada.gov.ua/ laws/show/2341-14.

30 Постанова пленуму Верховного суду України « Про судову практику в справах про злочини у сфері обігу наркотичних засобів, психотропних речовин, їх аналогів або прекурсорів» від 26.04.2002 № 4 (у редакції 18.12.2009): [Електронний ресурс]. - Режим доступу: http://zakon2.rada. gov.ua/laws/show/ v0004700-02. - Ст. 7. 
their analogues and precursors will reveal important aspects of committing crimes that will prevent them, including by knowing the potential victim of possible ways of committing them.

\section{SUMMARY}

The scientific study examines the mechanism of behavior of drug offenders. The stages of criminal activity are analyzed. The motives and motivation of the act were investigated. An attempt was made to conduct victimology modeling. The essence of the elements of the crime composition in the sphere of drug and psychotropic substances circulation, their analogues and precursors is revealed. The research is aimed at increasing the role of the need to study the "victim's person» as an integral part of the evidence base in the process of conducting search operations.

\section{REFERENCES}

1. Бажанов М.І., Баулін Ю.В., Борисов В.І. Кримінальне право України: Загальна частина: Підручник / За ред. проф. M.I. Бажанова, В.В. Сташиса, В.Я. Тація. - 2-е вид., перероб. і допов. - Київ : Юрінком Інтер, 2005. - 480 с.

2. Офіційний сайт Реєстр судових рішень. Справа № 500/4294/14-к. [Електронний ресурс]: Режим доступу: http://www.reyestr.court.gov.ua/ Review/42858627.

3. Невеликі, великі та особливо великі розміри наркотичних засобів, що знаходяться у незаконному обігу / Таблиця 1/ Затверджена наказом Міністерства охорони здоров'я України 01.08.2000 N 188 (у редакції 19.06.2015): [Електронний ресурс]. Режим доступу: http://zakon2.rada.gov.ua /laws/show/z0512-00.

4. Кодекс України про адміністративні правопорушення (статті 1 - 212-21) від 07.12.1984 № 8073-Х (у редакції 16.04.2017): [Електронний ресурс]. - Режим доступу: http://zakon2.rada.gov.ua/laws/show/80731-10.

5. Кримінальний кодекс України від 05.04.2001 № 2341-III (у редакції 16.04.2017): [Електронний ресурс]. - Режим доступу: http://zakon3.rada.gov.ua/laws/show/2341-14.

6. Офіційний сайт Реєстр судових рішень. Справа № 486/1038/15-к. [Електронний ресурс]: Режим доступу: http://reyestr.court.gov.ua/Review/ 54746382. 
7. Сайт Укрінформ. [Електронний ресурс]: Режим доступу: http://www.ukrinform.ua/ukr/news/urugvay_legalizuvav_marihuanu_ 1895217.

8. Науково-практичний коментар до Кримінального Кодексу України [Електронний ресурс]. - Режим доступу: http://pravoznavec.com.ua /books/162/28\#chlist.

9. Закон України «Про наркотичні засоби, психотропні речовини і прекурсори» від 15.02.1995 № 60/95-ВР (у редакції 28.12.2015): [Електронний ресурс]. - Режим доступу: http://zakon2.rada.gov.ua/laws/show/60/95-вр.

10.Ривман Д. В. Криминальная віктимологія : учеб. / Д. В. Ривман. - СПб. : Питер, 2002. - 304 с.

11.Постанова пленуму Верховного суду України «Про судову практику в справах про злочини у сфері обігу наркотичних засобів, психотропних речовин, їх аналогів або прекурсорів» від 26.04.2002 № 4 (у редакції 18.12.2009): [Електронний ресурс]. Режим доступу: http://zakon2.rada. gov.ua/laws/show/v0004700-02.

12.Кримінальний процесуальний кодекс України від 13.04.2012 № 4651-VI (у редакції 14.04.2017): [Електронний pecypc]. - Режим доступу: http://zakon2.rada.gov.ua/laws/ show/4651-17.

\section{Information about the author:} Klymiuk I. N., Lecturer of the Department of Administrative and Criminal Law Oles Honchar Dnipro National University 72, Gagarin Ave., Dnipro, Ukraine 